\title{
Assessment of Biological and Sanitary Condition of Alien Fish from a High-Mountain Lake (Cottian Alps)
}

\author{
Paolo Pastorino ${ }^{1,2}, *\left(\mathbb{0}\right.$, Marino Prearo ${ }^{2}$, Marco Bertoli ${ }^{1}$, Vasco Menconi $\left.{ }^{2}{ }^{(}\right)$, Giuseppe Esposito ${ }^{3}$, \\ Marzia Righetti ${ }^{2}{ }^{1}$, Davide Mugetti ${ }^{2}$, Sabina Pederiva ${ }^{2}$, Maria Cesarina Abete ${ }^{2}$ and \\ Elisabetta Pizzul ${ }^{1}$ (1) \\ 1 Department of Life Sciences, University of Trieste, via Giorgieri 10, 34127 Trieste, Italy; \\ marco.ber3@gmail.com (M.B.); pizzul@units.it (E.P.) \\ 2 The Veterinary Medical Research Institute for Piemonte, Liguria and Valle d'Aosta, Via Bologna 148, \\ 10154 Torino, Italy; marino.prearo@izsto.it (M.P.); vasco.menconi@izsto.it (V.M.); \\ marzia.righetti@gmail.com (M.R.); davide.mugetti@izsto.it (D.M.); sabina.pederiva@izsto.it (S.P.); \\ mariacesarina.abete@izsto.it (M.C.A.) \\ 3 Department of Veterinary Medicine, University of Sassari, via Vienna 2, 07100 Sassari, Italy; \\ gsesposito@uniss.it \\ * Correspondence: paolo.pastorino@izsto.it; Tel.: +39-011-268-6295
}

Received: 8 January 2020; Accepted: 14 February 2020; Published: 18 February 2020

\begin{abstract}
This study aimed to assess the biological and sanitary conditions of alien fish in a high-mountain lake (Balma Lake) located in the Cottian Alps. A single fish sampling session (August 2018) using gillnets collected 90 specimens of brook trout (Salvelinus fontinalis). Sex and age were determined (59 females and 31 males, age class $0+$ to $4+$ ). Regression analysis showed no difference in total weight and total length between males and females (ANCOVA: $\mathrm{F}=0.453 ; p=0.954$ ). The mean condition factor $\left(\mathrm{K}_{\text {mean }}\right)$ decreased with increasing age for males and females. Terrestrial insects were the main prey found in the fish stomachs. The parasitological exam was negative, and the bacteriological exam was positive for Carnobacterium maltaromaticum and C. divergens in 33\% of specimens. The total mercury, cadmium, and lead concentration in muscle tissue was within the maximum limit established by the European Commission for human consumption. The brook trout population was found to be well structured; these findings may help local administrations in the implementation of eradication measures.
\end{abstract}

Keywords: non-native species; Alpine lakes; Alps; brook trout; Carnobacterium spp.; heavy metals

\section{Introduction}

The environmental conditions of high-mountain lakes are extreme for survival (e.g., ice and snow cover for months, high UV-B radiation during the ice-free period) [1]. These once-pristine and unpolluted ecosystems due to their remote location have been under anthropogenic impact since the 1980s: deposition of pollutants transported from lowland emission sources and introduction of non-native fish species [2]. Isolated from watercourses by physical barriers that have prevented natural colonization by fish [3,4], high-mountain lakes can provide a habitat for alien fish species released for recreational fishing $[5,6]$. However, because originally fishless, high-mountain lakes have a low resilience to disturbances and can be especially sensitive to the introduction of alien fish that can significantly reduce or eliminate native organisms [6,7]. Studies in high-mountain lakes have focused mainly on the ecological effects of the introduction of alien fish on native fish species. Tiberti et al. [7] studied the pressure of brook trout (Salvelinus fontinalis) on crustacean zooplankton, macrobenthic invertebrates, and amphibians in lakes in the Italian Alps. Similar studies on lakes in the Pyrenees 
assessed the effects of non-native salmonids (Salmo trutta, Oncorhynchus mykiss, and Salvelinus fontinalis) and minnow (Phoxinus phoxinus) on local biodiversity [4].

The introduction of alien species can also cause the spread of pathogenic agents (e.g., parasites, bacteria, viruses, fungi) that may be more virulent in new hosts due to the lack of innate immunity in the native species [8]. To date, few studies have investigated the role that alien fish introduction can play in the dispersal of pathogens to a new environment. For example, Pseudorasbora parva (Cyprinidae) has been implicated in the introduction of pathogenic parasites (e.g., Sphaerothecum destruens) responsible for the decline of native fish in European freshwater bodies [9]. In their preliminary studies on fish sanitary condition after the introduction of alien fish in lakes in the Italian Alps, Pastorino et al. [10] isolated Yersinia ruckeri (the etiological agents of the enteric red mouth disease in salmonids) and Aeromonas spp. (ubiquitous in aquatic environments), which, because of their virulence and antibiotic resistance, could pose a threat for local amphibian species.

Stocking Italian mountain lakes with salmonids began in the 1960s when recreational angling became popular [11]. Brook trout Salvelinus fontinalis, native to eastern North America, has an almost worldwide distribution [12]; it is one of the most widely used non-native species for stocking high-mountain lakes [13]. It is appreciated by anglers for its readiness to take baits and by fishery managers for its ability to maintain itself in such marginal situations as are frequently found in high-mountain lakes. The main difficulties involved in studying alien fish populations in remote environments are access to the sites (most often only on foot), absence of information about the introduction/release (origin and date of fish stock), and angling impact. After their release in the Alpine lakes in Italy, brook trout have established reproductive populations in many lakes in the Cottian Alps, a mountain range in the southwestern Alps that forms a natural border between France (Hautes-Alpes and Savoie) and Italy (Piedmont).

Moreover, high-mountain lakes also act as a medium-to-long-term receptor for organic and inorganic pollutants from industrialized lowland regions [2]. Fish, being at the top of the trophic chain, may accumulate contaminants (e.g., trace elements) from dietary uptake [14].

With the present study, we assessed the biological (population structure and stomach content analysis) and sanitary conditions (parasitological and bacteriological exams) of a brook trout population in a typical high-mountain lake (Balma Lake) in Piedmont, northwest Italy. We also measured $\mathrm{Pb}, \mathrm{Cd}$, and $\mathrm{Hg}$ level in fish muscle to determine whether the concentration exceeded the maximum limit for human consumption established by the European Commission.

\section{Materials and Methods}

\subsection{Study Site}

Balma Lake ( $45^{\circ} 02^{\prime} 14^{\prime \prime}$ N; $07^{\circ} 10^{\prime} 52^{\prime \prime}$ E; Figure 1a) is located at $2100 \mathrm{~m}$ above sea level (a.s.l.) in the municipality of Coazze (Piedmont, northwest Italy) within the Site of Community Importance (SCI)/Special Areas of Conservation (SAC) IT1110006 - Orsiera Rocciavrè (Cottian Alps). The lake is covered by ice from November to early June. The main pressures are recreational fishing and grazing in summer. Originally a fishless lake, brook trout (Salvelinus fontinalis) was introduced probably in the 1970s for recreational fishing [10]. The lake measures $414 \mathrm{~m}$ in perimeter, 1.21 ha in surface area, and $6.42 \mathrm{~m}$ in maximum depth in the central zone. These data are provided by GeoStudio RC (Giaveno, Italy), which performed a morphometric and bathymetric survey of the lake using drones.

\subsection{Physicochemical Parameters of Water and Nutrients}

Water temperature $\left({ }^{\circ} \mathrm{C}\right), \mathrm{pH}$, conductivity $\left(\mu \mathrm{S} \mathrm{cm}{ }^{-1}\right)$, dissolved oxygen $\left(\mathrm{mg} \mathrm{L}^{-1}\right)$, and oxygen saturation (\%) were measured during a single fish sampling session (3 August 2018) at five sites in the littoral zone (L1-L5) in the first centimeters of water and at three sites in the deep zone (B1-B3) in the water column (Figure 1b) using portable probes (HI 9033 conductivity meter, HI $9125 \mathrm{pH} / \mathrm{ORP}$ meter, HI 9147 dissolved oxygen meter, Hanna Instruments Inc. Woonsocket, RI, USA). Three replicates 
were measured for each parameter. Water samples were collected at each site in sterile containers (three $1 \mathrm{~L}$ bottles for each site), taking care to avoid inclusion of sediment particles, and then brought to the laboratory in a refrigerated container within a few hours. Concentrations of $\mathrm{NH}_{4}^{+}\left(\mathrm{mg} \mathrm{L}^{-1}\right)$, $\mathrm{NO}_{3}{ }^{-}\left(\mathrm{mg} \mathrm{L}^{-1}\right)$, and $\mathrm{PO}_{4}{ }^{3-}\left(\mathrm{mg} \mathrm{L}^{-1}\right)$ were measured using a multi-parameter benchtop photometer (HI 83200-02, Hanna Instruments Inc.) according to the standard methods for water and wastewater examination [15].
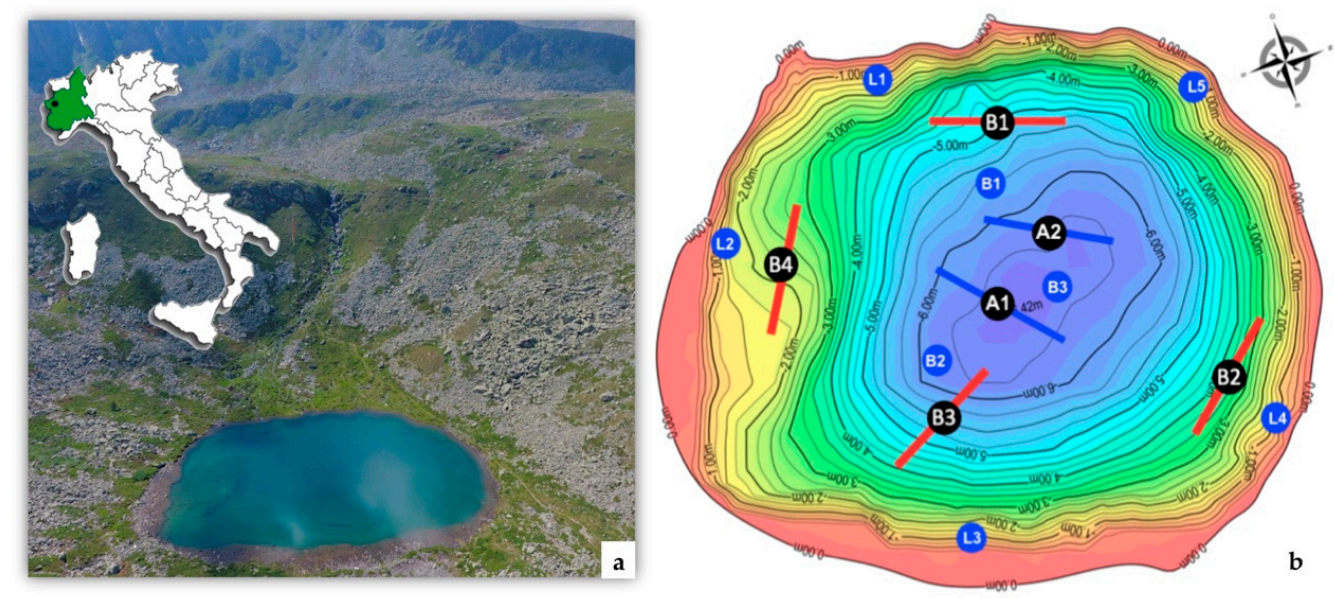

Figure 1. (a) Location of Balma Lake (northwest Italy). (b) Water sampling sites and gillnet placement. L1-L5 = littoral sites; B1-B3 = deep sites for sampling physicochemical parameters of water. Fish sampling: $\mathrm{B} 1-\mathrm{B} 4=$ benthic gillnets; $\mathrm{A} 1-\mathrm{A} 2$ = pelagic gillnets.

\subsection{Fish Sampling}

A single fish sampling session (3 August 2018) was performed following the protocol to assess the Lake Fish Index [16]. The protocol was developed from a standardized method for fish sampling in European lakes (EN 14757:2005) [17] that requires a single fish sampling session using benthic and pelagic gillnets in relation to the lake typology, depth, and surface area. Six gillnets were used for sampling: 2 pelagic (P) and 4 benthic (B) gillnets. The benthic gillnets ( $30 \mathrm{~m}$ long, $1.5 \mathrm{~m} \mathrm{high}, 45 \mathrm{~m}^{2}$ total surface area) were composed of 12 panels ( $2.5 \mathrm{~m}$ long) with a mesh size from 5 to $55 \mathrm{~mm}$ (Table 1). The pelagic gillnets ( $27.5 \mathrm{~m}$ long, $6 \mathrm{~m}$ high, $165 \mathrm{~m}^{2}$ total surface area) had the same sequence of panels as the benthic gillnets but lacked panel 5 (11 panels in total). Gillnets were placed according to the lake bathymetry profile (Figure 1b) [16]. Only benthic gillnets were placed in shallow water, while both pelagic and benthic gillnets were placed in the deeper water. The gillnets were placed at 6 p.m. and recovered $12 \mathrm{~h}$ later. Permission for fish sampling was obtained from the Città Metropolitana di Torino (authorization no. 176-19040/2017), as required by local laws.

Table 1. Sequence and mesh size (mm) of gillnets panels.

\begin{tabular}{cc}
\hline Panel (P) & Mesh Size (mm) \\
\hline 1 & 43 \\
2 & 19.5 \\
3 & 6.25 \\
4 & 5 \\
5 & 55 \\
6 & 8 \\
7 & 12.5 \\
8 & 24 \\
9 & 15.5 \\
10 & 10 \\
11 & 35 \\
12 & 29 \\
\hline
\end{tabular}




\subsection{Stomach Content Analysis}

Stomach content analysis was performed to obtain information about brook trout diet. The stomachs were sampled, preserved in 70\% alcohol, and then identified in the laboratory using a stereomicroscope (Zeiss Stemis V8, Carl Zeiss, Jena, Germany) and an optical microscope (Olympus BX40, Olympus, Tokyo, Japan). The ingested prey were identified to the order or family level because a more precise identification was often impossible due to the digestion status of the prey. Frequency of occurrence $(\mathrm{Fi})$ was calculated for the prey items to describe the diet [18]:

$$
\mathrm{Fi}=(\mathrm{Ni} / \mathrm{N}) 100,
$$

where $\mathrm{Ni}$ is the number of fish with prey $\mathrm{i}$ in their stomach and $\mathrm{N}$ is the total number of stomachs.

\subsection{Sanitary Condition Evaluation}

Specimens were necropsied and evaluated for possible pathological alterations. For the parasitological exam, tissue scrapings from skin and gill filaments were prepared with a drop of water, covered with a clean cover slip (wet mount preparation), and examined under an optical microscope (Olympus BX40, Olympus) at 10× to 40× magnification. The bacteriological exam was performed from the kidney, brain, and eye tissue (vitreous humor). The inoculum was directly plated out on first isolation media (Columbia Blood Agar or Tryptic Soy Agar) immediately after fish recovery from gillnets. The samples were incubated at $22 \pm 2{ }^{\circ} \mathrm{C}$ for $24-72 \mathrm{~h}$; the colonies were cloned and identified by matrix-assisted laser desorption ionization-time of flight mass spectrometry (MALDI-TOF MS) technology on a VITEK MS system (bioMérieux, France). Finally, lead (Pb) and cadmium (Cd) concentrations in muscle tissue were measured by inductively coupled plasma-mass spectrometry (ICP-MS Xseries II, Thermo Scientific, Bremen, Germany) after microwave digestion following the protocol described by Squadrone et al. [19]. Total mercury concentration was measured using a direct mercury analyzer (DMA-80 Analyzer from Milestone, Shelton, CT, USA). For heavy metal determination, five specimens of similar size (total length: $20 \pm 2 \mathrm{~cm}$ ) were selected and muscle tissue samples were taken from each fish. Samples were homogenized with an electric mill and divided into two samples: One to determine $\mathrm{Hg}$, the other to determine $\mathrm{Cd}$ and $\mathrm{Pb}$. The limit of quantification (LOQ) was $0.010 \mathrm{mg} \mathrm{kg}^{-1}$ for $\mathrm{Hg}$ and $0.020 \mathrm{mg} \mathrm{kg}^{-1}$ for $\mathrm{Cd}$ and $\mathrm{Pb}$.

\subsection{Biometric Measures and Statistical Analysis}

Catch per unit effort (CPUE) and biomass per unit effort (BPUE) were calculated for benthic and pelagic gillnets. CPUE was calculated as the number of fish per square meter of net per $12 \mathrm{~h} \mathrm{[20].}$ BPUE was determined as the weight ( $\mathrm{g}$ ) of fish per square meter of net per $12 \mathrm{~h} \mathrm{[21].} \mathrm{Furthermore,}$ the number and weight of each fish captured per net were recorded. The non-parametric Kruskal-Wallis test was used to compare the distribution of length of the fish captured with panels (P) of different mesh size. The Conover-Iman test was used as a post-hoc test to assess the presence of significant differences between panels of different mesh size.

Total length $\left(\mathrm{L}_{\mathrm{t}} ; \mathrm{cm}\right)$ and total weight $(\mathrm{W} ; \mathrm{g})$ were recorded for each specimen. Five scales above the lateral line were collected from each specimen to determine age. Scale annuli were identified using standard criteria based on the spacing and continuity of circuli around the scale, following the protocol by Zymonas and McMahon [22]. The relationship between total length and total weight for males and females was determined by non-linear regression [23]:

$$
\mathrm{W}=\mathrm{a} \mathrm{L}_{\mathrm{t}}^{\mathrm{b}}
$$

where $\mathrm{W}=$ fish weight $(\mathrm{g}) ; \mathrm{a}=$ intercept on the $y$-axis; $\mathrm{L}_{\mathrm{t}}=$ total fish length $(\mathrm{cm}) ; \mathrm{b}=$ exponent of the arithmetic form of the weight-length relationship and the slope of the regression line in the logarithmic form. The coefficient of determination $\left(\mathrm{r}^{2}\right)$ was obtained by curve interpolation and used to determine 
whether the curve values fit the data [24]. Analysis of covariance (ANCOVA) was used to compare $\mathrm{b}$-values as slopes of linear form of the standard length-weight regression equations. Differences in biometric parameters $\left(\mathrm{L}_{t}\right.$ and $\left.\mathrm{W}\right)$ between males and females of different age classes were checked using the non-parametric Mann-Whitney $U$ test. Fish health status was checked using the mean condition factor $\left(K_{\text {mean }}\right)$, which is the average condition factor for a given length obtained from the respective weight-length relationship [25], making it suitable for comparison of different populations of the same species. The mean condition factor was calculated as follows:

$$
\mathrm{K}_{\text {mean }}=100 \mathrm{a} \mathrm{L}_{\mathrm{t}}^{\mathrm{b}-3} \text {, }
$$

where $\mathrm{K}_{\text {mean }}=$ mean condition factor; $\mathrm{L}_{\mathrm{t}}=$ total length $(\mathrm{cm}) ; \mathrm{a}=$ coefficient of the arithmetic weight-length relationship and the intercept of the logarithmic form; $b=$ exponent of the arithmetic form of the weight-length relationship and the slope of the regression line in the logarithmic form. A non-parametric Kruskal-Wallis test followed by a post-hoc Conover-Iman test was used to detect significant differences in $\mathrm{K}_{\text {mean }}$ between age classes of males and females. The significance of the results was set at $p<0.05$. All analyses were performed using software RStudio version 1.1.463.

\section{Results}

\subsection{Hydrochemistry}

The temperature ranged from $14.60^{\circ} \mathrm{C}$ (site B1) to $16.10^{\circ} \mathrm{C}$ (site L4) in line with the seasonal trend. The conductivity was very low and ranged from $17 \mu \mathrm{S} \mathrm{cm}^{-1}$ (site B1) to $20 \mu \mathrm{S} \mathrm{cm}{ }^{-1}$ (site L4). Oxygenation ranged from $6.10 \mathrm{mg} \mathrm{L}^{-1}$ (site L1) to $8.80 \mathrm{mg} \mathrm{L}^{-1}$ (site B1). Oxygen saturation ranged between $86 \%$ and $101 \%$. pH ranged between 6.53 (site 1) and 7.31 (site 4). $\mathrm{NH}_{4}{ }^{+}$ranged from $0.04 \mathrm{mg} \mathrm{L}^{-1}$ (site L1) to $0.13 \mathrm{mg} \mathrm{L}^{-1}$ (site L4). $\mathrm{NO}_{3}{ }^{-}$ranged from $8.87 \mathrm{mg} \mathrm{L}^{-1}$ to $12.00 \mathrm{mg} \mathrm{L}^{-1}$. Finally, $\mathrm{PO}_{4}{ }^{3-}$ ranged from $0.01 \mathrm{mg} \mathrm{L}^{-1}$ (site L1) to $0.02 \mathrm{mg} \mathrm{L}^{-1}$ (site L3). Table 2 presents the mean and standard deviation (SD) of physicochemical characteristics.

Table 2. Mean and standard deviation (SD) of the physicochemical parameters of water.

\begin{tabular}{cccc}
\hline Parameter & \multicolumn{3}{c}{ Mean \pm SD } \\
\hline Temperature $\left({ }^{\circ} \mathbf{C}\right)$ & 16.08 & \pm 0.54 \\
Dissolved oxygen concentration $\left(\mathbf{m g ~ L}^{-1}\right)$ & 6.82 & \pm 0.42 \\
Oxygen saturation (\%) & 87.82 & \pm & 6.36 \\
$\mathbf{p H}$ & 6.70 & \pm & 0.34 \\
Conductivity $\left(\boldsymbol{\mu S ~ ~ ^ { - 1 }}\right)$ & 18.74 & \pm & 1.03 \\
$\mathbf{N H}_{\mathbf{4}}{ }^{+}\left(\mathbf{m g ~ L}^{-1}\right)$ & 0.09 & \pm & 0.07 \\
$\mathbf{N O}_{3-}\left(\mathbf{m g ~ L}^{-1}\right)$ & 9.59 & \pm & 1.67 \\
$\mathbf{P O}_{4}{ }^{3-}\left(\mathbf{m g ~ L}^{-1}\right)$ & 0.02 & \pm & 0.01 \\
\hline
\end{tabular}

\subsection{Fish Population}

A total of 90 specimens of brook trout (Salvelinus fontinalis) were collected. The number of fish ranged from 12 to 17 per benthic gillnet; 16 individuals were captured with both pelagic gillnets. The CPUE for benthic gillnets ranged from 0.267 (B1) to 0.378 (B4) fish per $\mathrm{m}^{2}$ per $12 \mathrm{~h}$. The CPUE was 0.100 fish per $\mathrm{m}^{2}$ per $12 \mathrm{~h}$ for the pelagic gillnets (A1 and A2). BPUE ranged from 21.39 to $24.05 \mathrm{~g} \mathrm{~m}^{-2}$ per $12 \mathrm{~h}$ for benthic gillnets and from 7.73 to $8.85 \mathrm{~g} \mathrm{~m}^{-2}$ per $12 \mathrm{~h}$ for pelagic gillnets (Table 3). 
Table 3. Number of fish (n) captured with pelagic (A) and benthic (B) gillnets; the catch per unit effort-CPUE (no. of fish per $\mathrm{m}^{2}$ per $12 \mathrm{~h}$ ), the weight (W; g) of each fish; and the biomass per unit effort-BPUE (weight of fish per $\mathrm{m}^{2}$ per $12 \mathrm{~h}$ ).

\begin{tabular}{ccccccc}
\hline Gillnet & A1 $\mathbf{( n = 1 6 )}$ & A2 $(\mathbf{n}=\mathbf{1 6})$ & B1 $(\mathbf{n}=\mathbf{1 2})$ & B2 $(\mathbf{n}=\mathbf{1 4})$ & B3 $(\mathbf{n}=\mathbf{1 5})$ & B4 $(\mathbf{n}=\mathbf{1 7})$ \\
\hline CPUE & $\mathbf{0 . 1 0 0}$ & $\mathbf{0 . 1 0 0}$ & $\mathbf{0 . 2 6 7}$ & $\mathbf{0 . 3 1 1}$ & $\mathbf{0 . 3 3 3}$ & $\mathbf{0 . 3 7 8}$ \\
\hline W1 & 78.26 & 67.53 & 58.72 & 116.53 & 18.41 & 18.45 \\
W2 & 146.86 & 79.55 & 73.58 & 98.35 & 17.29 & 15.12 \\
W3 & 120.16 & 53.16 & 64.59 & 45.81 & 58.75 & 17.34 \\
W4 & 92.80 & 94.46 & 71.24 & 50.49 & 14.75 & 20.87 \\
W5 & 114.85 & 96.58 & 44.52 & 54.76 & 11.70 & 38.23 \\
W6 & 109.4 & 61.10 & 128.00 & 65.32 & 6.07 & 43.02 \\
W7 & 93.45 & 50.64 & 133.41 & 50.90 & 14.70 & 50.46 \\
W8 & 97.53 & 45.44 & 122.89 & 61.75 & 102.2 & 56.54 \\
W9 & 73.02 & 62.71 & 107.24 & 60.65 & 138.63 & 59.87 \\
W10 & 52.64 & 58.78 & 100.94 & 92.05 & 131.99 & 61.67 \\
W11 & 113.44 & 111.75 & 105.23 & 49.63 & 83.74 & 69.98 \\
W12 & 77.91 & 71.39 & 72.06 & 62.25 & 91.99 & 67.43 \\
W13 & 89.88 & 133.82 & & 59.32 & 117.30 & 61.07 \\
W14 & 69.64 & 101.88 & & 104.17 & 112.74 & 101.4 \\
W15 & 47.85 & 68.02 & & & 42.17 & 116.32 \\
W16 & 82.21 & 118.96 & & & & 123.25 \\
W17 & & & & & & 146.7 \\
\hline BPUE & $\mathbf{8 . 8 5}$ & $\mathbf{7 . 7 3}$ & $\mathbf{2 4 . 0 5}$ & $\mathbf{2 1 . 6 0}$ & $\mathbf{2 1 . 3 9}$ & $\mathbf{2 3 . 7 3}$ \\
\hline
\end{tabular}

The mean fish biomass per unit effort was $17.89 \mathrm{~g} \mathrm{~m}^{-2}$ (summing the BPUE of the pelagic and the benthic gillnets). The distribution of the length of fish differed across panels (P) of different mesh size (Kruskal-Wallis test; $p=0.0013$ ); pairwise comparison showed significant differences in fish length distribution between P3 and P12 ( $p=0.0011)$, P5 and P12 $(p=0.0004)$, P8 and P12 ( $p=0.0010)$, P10 and P12 ( $p=0.0001)$, and P4 and P10 ( $p=0.0004)$ (Figure 2). No fish were captured in panels 1 $(43 \mathrm{~mm})$ and $11(35 \mathrm{~mm})$. Specimens smaller than $8 \mathrm{~cm}$ were not captured by the gillnets. These very small individuals inhabit shallow areas near the shoreline. These findings were derived from visual observations during gillnet placement.

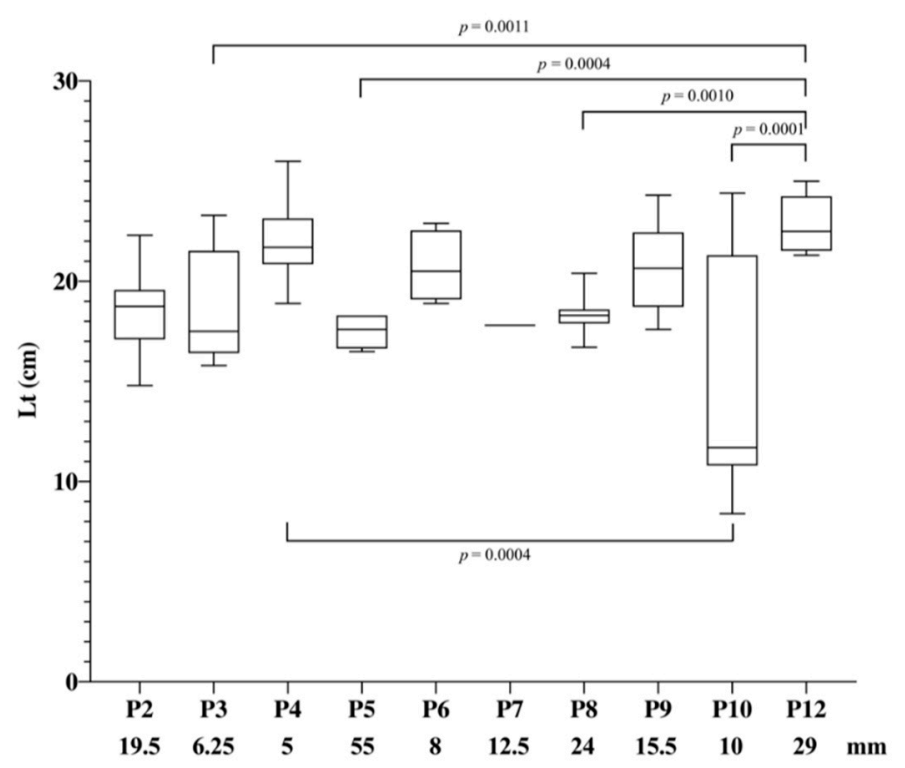

Figure 2. Distribution by total length $\left(\mathrm{L}_{\mathrm{t}}\right)$ of brook trout in relation to panel $(\mathrm{P})$ mesh size. 
Sex and age class were determined for all 90 specimens (59 females and 31 males, age class 0+ to $4+$ ). The highest number of individuals was recorded for age classes $1+$ and 2+ (Figure 3).

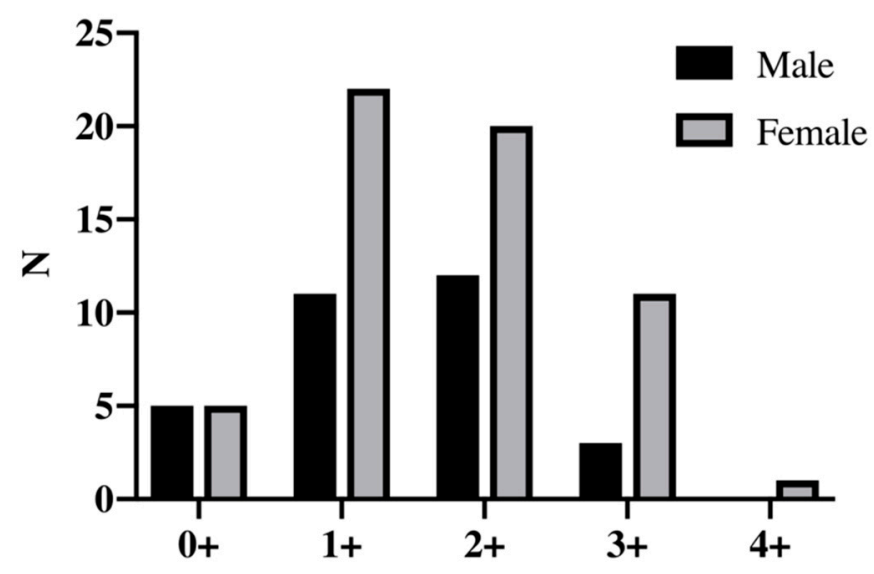

Figure 3. Distribution by age class of male and female S. fontinalis.

There were more females in all age classes (except for age $0+$, in which the number of males and females was the same). It is remarkable that the oldest recovered specimen (class 4+) was a female. Within each age class, $\mathrm{L}_{t}$ and $\mathrm{W}$ did not differ significantly between males and females (Table 4); length-weight regression showed clearly overlapping curves with a similar trend (Figure 4). Regression analysis between $\mathrm{W}$ and $\mathrm{L}_{t}$ did not differ significantly between males and females (ANCOVA $\mathrm{F}=0.453 ; p=0.954)$. Generally, the $\mathrm{K}_{\text {mean }}$ decreased with increasing age for both males and females (Table 5). $K_{\text {mean }}$ differed significantly across age classes for females (Kruskal-Wallis test; $p<0.0001$; Conover-Iman test $p<0.0001$ for all comparisons) and for males, except between age classes $2+$ and $3+$ (Kruskal-Wallis test; $p<0.0001$; Conover-Iman test $p<0.001$ for all comparisons, except between classes $2+$ and $3+, p>0.05)$.

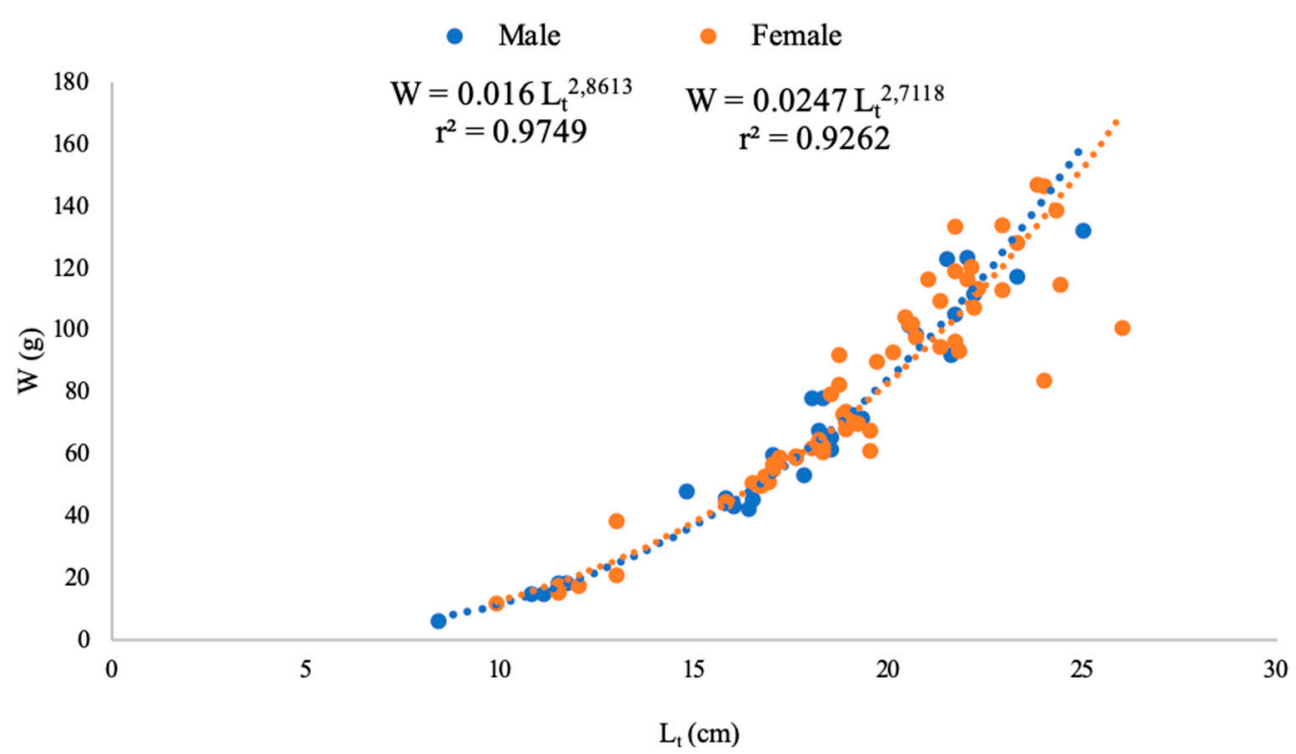

Figure 4. Relationship between total length $\left(\mathrm{L}_{\mathrm{t}}\right)$ and total weight $(\mathrm{W})$ in $\mathrm{S}$. fontinalis specimens (males and females). 
Table 4. Total length $\mathrm{L}_{t}(\mathrm{~cm})$ and total weight $\mathrm{W}(\mathrm{g})$ of male and female S. fontinalis (no.) for each age class.

\begin{tabular}{|c|c|c|c|c|c|c|c|}
\hline \multirow[t]{2}{*}{ Age Class } & & \multicolumn{2}{|c|}{ Females (F) } & \multicolumn{2}{|c|}{ Males (M) } & \multicolumn{2}{|c|}{$\begin{array}{c}\text { Mann-Whitney Test } \\
\text { (F vs. M) }\end{array}$} \\
\hline & & $\mathrm{L}_{\mathrm{t}}(\mathrm{cm})$ & W (g) & $\mathrm{L}_{\mathrm{t}}(\mathrm{cm})$ & W (g) & $\mathrm{L}_{\mathrm{t}}$ & $\mathbf{W}$ \\
\hline \multirow{7}{*}{$0+$} & Mean & 11.58 & 16.46 & 10.70 & 14.48 & \multirow{7}{*}{$p=0.3016$} & \multirow{7}{*}{$p=0.0659$} \\
\hline & Median & 11.50 & 17.29 & 11.10 & 14.75 & & \\
\hline & SD & 1.12 & 3.37 & 1.33 & 5.05 & & \\
\hline & Min & 9.90 & 11.70 & 8.40 & 6.07 & & \\
\hline & Max & 11.50 & 20.87 & 11.70 & 18.41 & & \\
\hline & CV \% & 9.68 & 20.45 & 12.00 & 34.24 & & \\
\hline & No. & \multicolumn{2}{|c|}{5} & \multicolumn{2}{|c|}{5} & & \\
\hline \multirow{7}{*}{$1+$} & Mean & 17.46 & 58.38 & 17.14 & 55.69 & \multirow{7}{*}{$p=0.4333$} & \multirow{7}{*}{$p=0.4625$} \\
\hline & Median & 17.40 & 58.73 & 17.00 & 53.16 & & \\
\hline & SD & 1.45 & 9.93 & 1.36 & 12.14 & & \\
\hline & Min & 13.00 & 38.23 & 14.80 & 42.17 & & \\
\hline & Max & 19.50 & 79.55 & 19.00 & 78.26 & & \\
\hline & $\mathrm{CV} \%$ & 8.28 & 17.00 & 7.99 & 22.83 & & \\
\hline & No. & \multicolumn{2}{|c|}{22} & \multicolumn{2}{|c|}{11} & & \\
\hline \multirow{7}{*}{$2+$} & Mean & 20.48 & 97.41 & 19.92 & 86.38 & \multirow{7}{*}{$p=0.2589$} & \multirow{7}{*}{$p=0.1821$} \\
\hline & Median & 20.55 & 99.70 & 19.90 & 84.95 & & \\
\hline & SD & 1.38 & 18.84 & 1.87 & 22.68 & & \\
\hline & Min & 18.30 & 62.25 & 17.60 & 58.78 & & \\
\hline & Max & 22.90 & 133.41 & 23.30 & 122.89 & & \\
\hline & $\mathrm{CV} \%$ & 6.76 & 19.34 & 9.39 & 26.25 & & \\
\hline & No. & \multicolumn{2}{|c|}{20} & \multicolumn{2}{|c|}{12} & & \\
\hline \multirow{7}{*}{$3+$} & Mean & 23.06 & 119.64 & 23.07 & 122.33 & \multirow{7}{*}{$p=0.9725$} & \multirow{7}{*}{$p=0.999$} \\
\hline & Median & 23.30 & 118.96 & 22.20 & 123.25 & & \\
\hline & SD & 1.14 & 21.50 & 1.68 & 10.15 & & \\
\hline & Min & 21.30 & 83.74 & 22.00 & 123.25 & & \\
\hline & Max & 24.40 & 146.86 & 25.00 & 131.99 & & \\
\hline & CV \% & 4.96 & 17.97 & 7.27 & 8.30 & & \\
\hline & No. & \multicolumn{2}{|c|}{11} & \multicolumn{2}{|c|}{3} & & \\
\hline \multirow{7}{*}{$4+$} & Mean & 26.00 & 100.94 & - & - & & \\
\hline & Median & - & - & - & - & & \\
\hline & SD & - & - & - & - & & \\
\hline & Min & - & - & - & - & & \\
\hline & Max & - & - & - & - & & \\
\hline & CV \% & - & - & - & - & & \\
\hline & No. & \multicolumn{2}{|c|}{1} & \multicolumn{2}{|c|}{0} & & \\
\hline
\end{tabular}

Table 5. Age class, sex, and relative $\mathrm{K}_{\text {mean }}$ (mean \pm standard deviation) for $S$. fontinalis.

\begin{tabular}{ccc}
\hline Age & Sex & $\mathbf{K}_{\text {mean }}$ \\
\hline \multirow{2}{*}{$0+$} & $\mathrm{M}$ & $1.03 \pm 0.04$ \\
& $\mathrm{~F}$ & $1.14 \pm 0.01$ \\
\hline \multirow{2}{*}{$1+$} & $\mathrm{M}$ & $0.89 \pm 0.02$ \\
& $\mathrm{~F}$ & $1.08 \pm 0.01$ \\
\hline \multirow{2}{*}{$2+$} & $\mathrm{M}$ & $0.86 \pm 0.02$ \\
& $\mathrm{~F}$ & $1.05 \pm 0.01$ \\
\multirow{2}{*}{$3+$} & $\mathrm{M}$ & $0.82 \pm 0.02$ \\
& $\mathrm{~F}$ & $1.03 \pm 0.01$ \\
\hline \multirow{2}{*}{$4+$} & $\mathrm{M}$ & - \\
& $\mathrm{F}$ & 1.01 \\
\hline
\end{tabular}


The mean and standard deviation of prey items per stomach was $14.63 \pm 14.71$ (range 2-70). We identified three prey groups (Diptera Chironomidae, Imenoptera, and Coleoptera) and grouped them into two macrogroups (benthic invertebrates and terrestrial invertebrates). Table 6 presents a summary of the diet of $S$. fontinalis.

Table 6. Diet of Salvelinus fontinalis; Fi = frequency of occurrence (in percentage).

\begin{tabular}{cc}
\hline Prey Group & Fi (\%) \\
\hline Benthic invertebrates & 7.55 \\
Diptera Chironomidae & 7.55 \\
Terrestrial invertebrates & $\mathbf{8 3 . 5 5}$ \\
Imenoptera & 68.00 \\
Formicidae & 1.33 \\
Coleoptera & 15.55 \\
\hline
\end{tabular}

\subsection{Sanitary Condition of Fish}

No clinical signs of disease or pathological alterations were noted. The parasitological exam was negative, while the bacteriological exam was positive for Carnobacterium maltaromaticum and C. divergens in $33 \%$ of individuals and was isolated from the eye. $\mathrm{Cd}$ was $<\mathrm{LOQ} ; \mathrm{Pb}$ ranged from 0.041 to $0.12 \mathrm{mg} \mathrm{kg}^{-1}$ (mean \pm SD: $0.070 \pm 0.034$ ) and $\mathrm{Hg}$ from 0.013 to $0.015 \mathrm{mg} \mathrm{kg}^{-1}$ (mean \pm SD: $0.014 \pm 0.001)$.

\section{Discussion}

The physicochemical characteristics of water were consistent with those reported by Tiberti et al. [26] for 12 Alpine lakes in Gran Paradiso National Park (Western Alps, Italy). As Balma Lake lies on granite bedrock, its $\mathrm{pH}$ is lower compared to lakes on limestone or sandstone bedrock [27]. The $\mathrm{pH}$ was in line with the published literature on high-altitude lakes [28-30]. The oxygenation level was high, as expected for mountain lakes. The low conductivity was also in line with the literature: The conductivity of silty-like lakes tends to be $<50 \mu \mathrm{S} \mathrm{cm}^{-1}$ [28-30]. No decrease in oxygen with depth was observed, consistent with the absence of temperature stratification. Nutrient levels $\left(\mathrm{NH}_{4}{ }^{+}\right.$, $\mathrm{NO}_{3}{ }^{-}$, and $\mathrm{PO}_{4}{ }^{3-}$ ) showed water oligotrophy and were also in line with previous studies on Alpine lakes [27-30].

Gillnets of smaller mesh size are not very selective for fish. P10 (mesh size $10 \mathrm{~mm}$ ) captured specimens from 8.4 to $24.4 \mathrm{~cm}$. The capture efficiency was dictated by the ability of the smaller mesh size to entangle the fish. These observations are shared by Tiberti et al. [31] who showed that gillnets with a mesh size from 10 to $25 \mathrm{~mm}$ entangled brook trout of different size in four high-altitude lakes in the Italian Alps. By contrast, larger mesh sizes $(35,43,55 \mathrm{~mm})$ were too large to efficiently capture the relatively small brook trout in Balma Lake. Cavalli et al. [20] observed in Plan Vianney Lake (French Alps, $2250 \mathrm{~m}$ a.s.1.) that the CPUE of the surface and bottom nets for S. fontinalis was 0.02 individuals $\mathrm{m}^{-2} \mathrm{~h}^{-1}$. Our hourly CPUE values were similar: 0.008 individuals $\mathrm{m}^{-2} \mathrm{~h}^{-1}$ for both pelagic gillnets and $0.02-0.03$ individuals $\mathrm{m}^{-2} \mathrm{~h}^{-1}$ for benthic gillnets.

In a study on a brook trout population from Grand Mesa, Uncompahgre, and Gunnison National Forests (USA), Adams et al. [32] sampled both juveniles and adults: Only $16 \%$ of the total fish sampled were larger than $20 \mathrm{~cm}$ (most ranging between 7.5 and $25.0 \mathrm{~cm}$ ) similar to our results. Changes in mean length reflect the trophic condition of the environment. For example, the brook trout population in an ultraoligotrophic high-altitude lake (2703 m a.s.l.) in the Western Alps measured 15-18 cm in total length at age $3+$ and $20-22 \mathrm{~cm}$ at age 5+ [33]. In contrast, the brook trout in Lake Nero (Western Alps, $2007 \mathrm{~m}$ a.s.1.) measured $18-20 \mathrm{~cm}$ at age $2+$, as this is a more productive environment [34].

The mean biomass of the brook trout in Balma Lake $\left(17.89 \mathrm{~g} \mathrm{~m}^{-2}\right)$ was similar to that recorded for Lake Dres $\left(18 \mathrm{~g} \mathrm{~m}^{-2}\right)$ in Gran Paradiso National Park, Italy [31]. Lake Dres is similar in hydrochemistry (phosphorus $0.04 \mathrm{mg} \mathrm{L}^{-1}$; pH $\left.7 \pm 0.5\right)$, altitude (2087 $\mathrm{m}$ a.s.l.), and depth (7.4 m) to Balma Lake. 
The biomass of the brook trout population is related to its abundance, phosphorus concentration, and altitude, which are related to the trophic and thermal state of Alpine lakes [31]. Balma Lake lies at $2100 \mathrm{~m}$ a.s.l and is characterized by oligotrophic conditions $\left(\mathrm{P}<0.02 \mathrm{mg} \mathrm{L}^{-1}\right)$; under such conditions, brook trout cannot grow to considerable biomass.

In our study, the scalimetric method for age determination was found to be reliable for small specimens, which have a relatively stable growth rate. For larger specimens (standard length $>15 \mathrm{~cm}$ ), however, in which growth rates vary and can rapidly decrease, this method may underestimate specimen age [35]. This problem was reported by Dutil and Power [36] for brook trout. Kozel and Hubert [37] found that neither scales nor otoliths produce reliable age estimates for brook trout from a high-elevation environment, and that age estimates based on otoliths tended to be higher than those based on scales. Accordingly, we did not analyze otoliths in this study. Nevertheless, the age structure of the brook trout population from Balma Lake was the same as that obtained by Šanda et al. [35] that reported a maximum age of $4+$ for brook trout in two high-mountain lakes. Our findings are shared by other studies that the majority of brook trout populations reach their maximum age of $3+$ or $4+$ in high-altitude environments [38-41].

Several mechanisms may influence the sex ratio, which constitutes a parameter of pivotal importance for population viability [42]. In our study, the higher number of females than males may be explained by the low water temperature throughout the year. Pavlidis et al. [43] showed that temperature during very early developmental stages is a key factor for sex differentiation: Low rearing temperatures $\left(13-15^{\circ} \mathrm{C}\right.$ ) result in higher proportions of females. Furthermore, epigenetic mechanisms can work with genomic and environmental factors to modify gene activity that generates a particular phenotype and sex determination as a consequence [44].

The mean condition factor $\left(\mathrm{K}_{\text {mean }}\right)$ showed a declining trend from age $0+$ to $4+$ in line with the changes in body length, indicating a steady loss of weight in relation to length. Compared to females, the $\mathrm{K}_{\text {mean }}$ for males was lower across all age classes, which could suggest differences in the use of resources for growth. Unfortunately, we have no $\mathrm{K}_{\text {mean }}$ data for brook trout from other mountain lakes for possible comparison. Nevertheless, Reimers [45] showed a downward trend for Fulton's condition factor $(K)$ in brook trout from a small high-altitude lake in the eastern Sierra Nevada. Cavalli et al. [20] reported a minimum condition factor of 0.86 in May of brook trout from Plan Vianney Lake (French Alps), which was indicative of poor food availability, whereas with the increased availability of prey, the condition factor rose to close to 1.1 in July-August.

Summer food of brook trout consists mainly of terrestrial insects, accounting for more than $80 \%$ of food intake [46]. We found that the brook trout feed on mostly terrestrial invertebrates. This observation is consistent with the two-year study by Utz and Hartman [47] on brook trout diet in the Appalachian Mountains of Randolph County (West Virginia). They found that during warmer months, the fish feed on terrestrial invertebrates, whereas aquatic animals and macrobenthic invertebrates contributed less to sustaining the brook trout populations. In our study, we noted that the benthic component accounted for only a limited portion of the diet. The large number of taxa found in the stomachs revealed, however, that Salvelinus fontinalis is an opportunistic and visual predator, as reported elsewhere [18,47]. The finding of taxa belonging to the Formicidae family showed that brook trout also feed on organisms that accidentally fall into the water, underlining the opportunistic dietary behavior of this salmonid. The observed prevalence of terrestrial invertebrates in the diet of brook trout in Balma Lake is shared by previous studies on the same species in other Alpine lakes [18,46-49].

The aquatic communities of invertebrates in mountain lakes are composed of few taxa: Diptera Chironomidae (Hexapoda) and Oligochaeta may make up more than 70\% of the whole community $[28,29,50,51]$. Only members of the Chironomidae family were found in the fish stomachs, albeit at low frequency. Hyslop [52] found that Oligochaeta are underrepresented in the fish diet due to their poor resistance to digestion, which can hamper their occurrence. Our results show that the brook trout population has a negative pressure on terrestrial insects. Stocking fish into fishless lakes is known to trigger negative effects that propagate through the whole food web [53]. For example, stocking 
arctic char (Salvelinus alpinus) into streams resulted in a reduction of emergency rate by macrobenthic invertebrates, with consequences for spiders and birds that inhabit the riparian zone [54,55]. A decrease in carbon flux from aquatic to terrestrial ecosystems has also been noted [56]. Furthermore, negative pressure on terrestrial invertebrates can also affect the pollination of terrestrial plants [57].

Finally, regarding the evaluation of sanitary condition, the bacteriological exam was positive for Carnobacterium maltaromaticum and C. divergens. Carnobacterium is a genus of Gram-positive bacteria within the family Carnobacteriaceae. These bacteria are frequently isolated from diverse environments and foods [58]. Furthermore, C. maltaromaticum (previously C. piscicola) was also isolated. Considered an opportunistic pathogen [59], this bacterium has been associated with renal congestion, splenomegaly, thickening of the swim bladder wall, and accumulation of a mucoid exudate in the lake whitefish (Coregonus clupeaformis) from Lake Michigan [60]. We observed no clinical signs in the brook trout from Balma Lake. The isolation of Carnobacterium leads us to hypothesize that this opportunist pathogen may remain in a sort of latent state in the eye (Trojan horse effect as described by Zlotkin et al. [61]), but then exert its pathogenic action when immune defenses are reduced due to stress caused by adverse environmental conditions. The pathogenesis of Carnobacterium needs to be better studied and investigated.

Trace element accumulation in aquatic organisms from high-mountain lakes has mostly focused on fish. For example, Köck et al. [62] detected $\mathrm{Cd}, \mathrm{Pb}, \mathrm{Zn}$, and $\mathrm{Cu}$ in S. alpinus from five oligotrophic lakes in the Tyrolean Alps (Austria) and showed that the levels were similar to those recorded in fish from freshwater polluted by direct discharge of metals. These findings suggest that mountain lakes are an important sink site for contaminants transported from industrialized lowland areas. We measured mercury levels of $<0.015 \mathrm{mg} \mathrm{kg}^{-1}$ in all samples, which is far below the maximum limit $\left(0.5 \mathrm{mg} \mathrm{kg}^{-1}\right)$ set by EU Regulation 1881/2006 [63] and subsequent amendments for human consumption. Rognerud et al. [64] found that $\mathrm{Hg}$ concentrations in fish from European Alpine lakes ranged from 0.021 to $0.179 \mathrm{mg} \mathrm{kg}^{-1}$, similar to our results. The cadmium content was also below the LOQ $\left(<0.02 \mathrm{mg} \mathrm{kg}^{-1}\right)$ in all samples and within the limit $\left(0.05 \mathrm{mg} \mathrm{kg}^{-1}\right)$ for cadmium in fish muscle [63]. The mean lead level was $0.064 \mathrm{mg} \mathrm{kg}^{-1}$, also below the limit of $0.30 \mathrm{mg} \mathrm{kg}^{-1}$ [63]. As no previous studies have been performed, we assume that the heavy metals detected in the brook trout from Balma Lake originate from anthropogenic and pedogenic sources.

\section{Conclusions}

Our findings show that the brook trout population in Balma Lake is well structured, with individuals in age class from $0+$ to $4+$. As fish sampling was performed only with gillnets, no smaller fish $(<8 \mathrm{~cm})$ were caught. This precluded evaluation of the fish pressure on zooplankton, the main prey ingested by young brook trout [18]. We did find a high predation pressure on terrestrial insects, however. Areas surrounding the lake include protected habitats. For example, Alpine prairies are included in annex I of the "Habitat Directive" 92/43/EEC [65] and host endangered species, which can be negatively impacted by the direct and/or indirect effects of fish predation. These considerations should be considered by local administrations for the implementation of concrete conservation actions such as fish eradication. As all heavy metal concentrations are in line with the limit established by the European Commission for human consumption, parallel strategies close to eradication may also be implemented, for example, the use of angling sessions to support eradication campaigns.

Author Contributions: Conceptualization, P.P.; Data curation, P.P., M.P. and E.P.; Formal analysis, M.B.; Investigation, P.P., M.B., V.M., G.E., M.R., D.M., S.P., M.C.A. and E.P.; Methodology, P.P., M.P., M.B., V.M., G.E., M.R., D.M., S.P. and E.P.; Supervision, E.P.; Writing - original draft, P.P.; Writing - review \& editing, M.P., M.B., M.C.A. and E.P. All authors have read and agreed to the published version of the manuscript.

Funding: This study was partly funded by Fondazione CRT “Richieste Ordinarie” Progetto ALPLA (18D03).

Acknowledgments: The authors would like to thank GeoStudio RC (Marco Rosa Clot, Luca Rosa Clot), Club Alpino Italiano (Alfio Usseglio), and Ente di Gestione delle Aree Protette delle Alpi Cozie (Michele Ottino) for their technical support. 
Conflicts of Interest: The authors declare no conflict of interest.

\section{References}

1. Catalan, J.; Camarero, L.; Felip, M.; Pla, S.; Ventura, M.; Buchaca, T.; Medina-Sánchez, J.M. High mountain lakes: Extreme habitats and witnesses of environmental changes. Limnetica 2006, 25, 551-584.

2. Pastorino, P.; Pizzul, E.; Bertoli, M.; Perilli, S.; Brizio, P.; Salvi, G.; Esposito, G.; Abete, M.C.; Prearo, M.; Squadrone, S. Macrobenthic invertebrates as bioindicators of trace elements in high-mountain lakes. Environ. Sci. Pollut. Res. 2019. [CrossRef] [PubMed]

3. Knapp, R.A.; Corn, P.S.; Schindler, D.E. The introduction of nonnative fish into wilderness lakes: Good intentions, conflicting mandates, and unintended consequences. Ecosystems 2001, 4, 275-278. [CrossRef]

4. Miró, A.; Ventura, M. Historical use, fishing management and lake characteristics explain the presence of non-native trout in Pyrenean lakes: Implications for conservation. Biol. Conserv. 2013, 167, 17-24. [CrossRef]

5. Pister, E.P. Wilderness fish stocking: History and perspective. Ecosystems 2001, 4, 279-286. [CrossRef]

6. Schindler, D.E.; Parker, B.R. Biological pollutants: Alien fishes in mountain lakes. Water Air Soil Poll. 2002, 2, 379-397. [CrossRef]

7. Tiberti, R.; von Hardenberg, A.; Bogliani, G. Ecological impact of introduced fish in high altitude lakes: A case of study from the European Alps. Hydrobiologia 2014, 724, 1-19. [CrossRef]

8. Pastorino, P.; Bona, C.; Foglini, C.; Maurella, C.; Righetti, M.; Burioli, E.; Ru, G.; Pizzul, E.; Prearo, M. Health risks related to freshwater fish handling and introduction of alien species. IJFI 2017, 4, 109-116.

9. Gozlan, R.E.; St-Hilaire, S.; Feist, S.W.; Martin, P.; Kent, M.L. Disease threat to European fish. Nature 2005, 435, 1046. [CrossRef]

10. Pastorino, P.; Polazzo, F.; Bertoli, M.; Santi, M.; Righetti, M.; Pizzul, E.; Prearo, M. Consequences of fish introduction in fishless Alpine lakes: Preliminary notes from a sanitary point of view. Turk. J. Fish. Aquat. Sci. 2020, 20, 1-8. [CrossRef]

11. Cantonati, M.; Lapini, L.; Paradisi, S.; Stoch, F. Conservation and management. In High-Altitude Lakes, Quaderni Habitat. Ministero dell' Ambiente e Della Tutela del Territorio, English ed.; Stoch, F., Ed.; Museo Friulano di Storia Naturale: Udine, Italy, 2006; Volume 4, pp. 123-135.

12. MacCrimmon, H.R.; Gots, B.L.; Campbell, J.S. World distribution of Brook Trout, Salvelinus fontinalis: Further observations. Can. J. Fish. Aquat. Sci. 1971, 28, 452-456. [CrossRef]

13. Savini, D.; Occhipinti-Ambrogi, A.; Marchini, A.; Tricarico, E.; Gherardi, F.; Olenin, S.; Gollasch, S. The top 27 animal alien species introduced into Europe for aquaculture and related activities. J. Appl. Ichthyol. 2010, 26, 1-7. [CrossRef]

14. Pastorino, P.; Elia, A.C.; Caldaroni, B.; Menconi, V.; Abete, M.C.; Brizio, P.; Bertoli, M.; Zaccaroni, A.; Magara, G.; Dörr, A.M.J.; et al. Oxidative stress ecology in brook trout (Salvelinus fontinalis) from a high-mountain lake (Cottian Alps). Sci. Total Environ. 2020. [CrossRef] [PubMed]

15. APHA; AWWA; WEF. Standard Methods for the Examination of Water and Wastewater, 20th ed.; American Public Health Association, American Water Work Association, Water Environment Federation: Washington, DC, USA, 1998.

16. Volta, P. Indice per L'analisi Dello Stato di Qualità Della Fauna Ittica Finalizzato Alla Valutazione Dello Stato Ecologico dei Laghi Italiani: Lake Fish Index (LFI). Indici per la Valutazione Della Qualità Ecologica dei Laghi. CNR, Istituto per lo Studio degli Ecosistemi, Verbania Pallanza. Available online: https: //core.ac.uk/download/pdf/37834548.pdf (accessed on 30 December 2019).

17. CEN. Water Quality-Sampling of Fish with Multi-mesh Gillnets (EN 14757: 2005); CEN: Brussels, Belgium, 2005.

18. Tiberti, R.; Brighenti, S.; Canedoli, C.; Iacobuzio, R.; Rolla, M. The diet of introduced brook trout (Salvelinus fontinalis; Mitchill, 1814) in an alpine area and a literature review on its feeding ecology. J. Limnol. 2016, 75, 488-507. [CrossRef]

19. Squadrone, S.; Brizio, P.; Stella, C.; Prearo, M.; Pastorino, P.; Serracca, L.; Ercolini, C.; Abete, M.C. Presence of trace metals in aquaculture marine ecosystems of the northwestern Mediterranean Sea (Italy). Environ. Pollut. 2016, 215, 77-83. [CrossRef]

20. Cavalli, L.; Chappaz, R.; Bouchard, P.; Brun, G. Food availability and growth of the brook trout, Salvelinus fontinalis (Mitchill), in a French Alpine lake. Fish. Manag. Ecol. 1997, 4, 167-177. [CrossRef] 
21. Alexander, T.J.; Vonlanthen, P.; Periat, G.; Degiorgi, F.; Raymond, J.C.; Seehausen, O. Estimating whole-lake fish catch per unit effort. Fish. Res. 2015, 172, 287-302. [CrossRef]

22. Zymonas, N.D.; McMahon, T.E. Comparison of pelvic fin rays, scales and otoliths for estimating age and growth of bull trout, Salvelinus confluentus. Fish. Manag. Ecol. 2009, 16, 155-164. [CrossRef]

23. Ricker, W.E. Computation and Interpretation of Biological Statistics of Fish Populations; Department of the Environment, Fisheries and Marine Service: Ottawa, ON, Canada, 1975; pp. 1-382.

24. Treer, T.; Sprem, N.; Torcu-Koc, H.; Sun, Y.; Piria, M. Short communication Length-weight relationships of freshwater fishes of Croatia. J. Appl. Ichthyol. 2008, 24, 626-628. [CrossRef]

25. Froese, R. Cube law, condition factor and weight-length relationships: History, meta-analysis and recommendations. J. Appl. Ichthyol. 2006, 22, 241-253. [CrossRef]

26. Tiberti, R.; Tartari, G.A.; Marchetto, A. Geomorphology and hydrochemistry of 12 Alpine lakes in the Gran Paradiso National Park, Italy. J. Limnol. 2010, 69, 242-256. [CrossRef]

27. Camarero, L.; Rogora, M.; Mosello, R.; Anderson, N.J.; Barbieri, A.; Botev, I.; Kernan, M.; Kopàćek, J.; Korhola, A.; Lotter, A.F.; et al. Regionalization of chemical variability in European mountain lakes. Freshw. Biol. 2009, 54, 2452-2469. [CrossRef]

28. Boggero, A.; Füreder, L.; Lencioni, V.; Simcic, T.; Thaler, B.; Ferrarese, U.; Lotter, A.F.; Ettinger, R. Littoral chironomid communities of Alpine lakes in relation to environmental factors. Hydrobiologia 2006, 562, 145-165. [CrossRef]

29. Füreder, L.; Ettinger, R.; Boggero, A.; Thaler, B.; Thies, H. Macroinvertebrate diversity in Alpine lakes: Effects of altitude and catchment properties. Hydrobiologia 2006, 652, 123-144. [CrossRef]

30. Fjellheim, A.; Raddum, G.V.G.; Vandvik, V.; Cogălniceanu, D.; Boggero, A.; Brancelj, A.; Galas, J.; Sporka, F.; Vidinova, Y.; Bitusik, P.; et al. Diversity and distribution patterns of benthic invertebrates along alpine gradients. A study of remote European freshwater lakes. Adv. Limnol. 2009, 62, 167-190.

31. Tiberti, R.; Nelli, L.; Brighenti, S.; Iacobuzio, R.; Rolla, M. Spatial distribution of introduced brook trout Salvelinus fontinalis (Salmonidae) within alpine lakes: Evidences from a fish eradication campaign. Eur. Zool.J. 2017, 84, 73-88. [CrossRef]

32. Adams, P.; James, C.; Speas, C. Brook trout (Salvelinus fontinalis). Species and Conservation Assessment. Grand Mesa, Uncompahgre, and Gunnison National Forests. Available online: https://www.fs.usda.gov/ Internet/FSE_DOCUMENTS/stelprdb5199816.pdf (accessed on 30 December 2019).

33. Alessio, G.; Forneris, G.; Confortini, I. Indagini preliminari su accrescimento, biologia e ambientamento del salmerino di fontana, Salvelinus fontinalis Mitch., in un ecosistema lacustre di alta quota. Atti Società Italiana Scienze Naturali 1987, 128, 138-152.

34. Forneris, G. Piemonte. Acque. Pesci. Pesca; EDA: Torino, Italy, 1984; pp. 1-96.

35. Šanda, R.; Miroslav Švátora, M.; Vukić, J.; Hořicka, Z.; Sychrová, O.; Marić, S. Evaluation of the temporal development of three introduced populations of brook trout, Salvelinus fontinalis, in Jizerské Mountains (Czech Republic). Arch. Biol. Sci. 2015, 67, 775-784. [CrossRef]

36. Dutil, J.D.; Power, G. Validité de la lecture das otolithes comparée à celle de la lecture des écailles pour la détermination de l'âge de l'omble de fontaine (Salvelinus fontinalis). Nat. Can. 1977, 104, 361-367.

37. Kozel, S.J.; Hubert, W.A. Age estimates of brook trout from high-elevation Rocky Mountain streams using scales and otoliths. Northwest Sci. 1987, 61, 216-219.

38. McFadden, J.T. A population study of the Brook Trout, Salvelinus fontinalis. Wildl. Monogr. 1961, 7, 3-73.

39. Wydoski, R.S.; Cooper, E.L. Maturation and fecundity of brook trout from infertile streams. Can. J. Fish. Aquat. Sci. 1966, 23, 623-649. [CrossRef]

40. Flick, W.A.; Webster, D.A. Production of wild, domestic, and interstrain hybrids of brook trout (Salvelinus fontinalis) in natural ponds. JFRBC 1976, 33, 1525-1539. [CrossRef]

41. Quinn, N.W.; Korver, R.M.; Hicks, F.J.; Monroe, B.P.; Hawkins, R.R. An empirical model of lentic brook trout. N. Am. J. Fish. Manag. 1994, 14, 692-709. [CrossRef]

42. Ospina-Alvarez, N.; Piferrer, F. Temperature-dependent sex determination in fish revisited: Prevalence, a single sex ratio response pattern, and possible effects of climate change. PLoS ONE 2008, 3, e2837. [CrossRef] [PubMed]

43. Pavlidis, M.; Koumoundouros, G.; Sterioti, A.; Somarakis, S.; Divanach, P.; Kentouri, M. Evidence of temperature-dependent sex determination in the European sea bass (Dicentrarchus labrax L.). J. Exp. Zool. 2000, 287, 225-232. [CrossRef] 
44. Piferrer, F.; Anastasiadi, D.; Valdivieso, A.; Sánchez-Baizán, N.; Moraleda-Prados, J.; Ribas, L. The Model of the Conserved Epigenetic Regulation of Sex. Front. Genet. 2019, 10, 857. [CrossRef] [PubMed]

45. Reimers, N. Conditions of existence, growth, and longevity of brook trout in a small high-altitude lake of the Eastern Sierra Nevada. Calif. Fish. Game 1958, 44, 319-333.

46. Dawidowicz, P.; Gliwicz, Z.M. Food of brook charr in extreme oligotrophic conditions of an alpine lake. Environ. Biol. Fish. 1983, 8, 55-60. [CrossRef]

47. Utz, R.M.; Hartman, K.J. Identification of critical prey items to Appalachian brook trout (Salvelinus fontinalis) with emphasis on terrestrial organisms. Hydrobiologia 2007, 575, 259-270. [CrossRef]

48. Lacasse, S.; Magnan, P. Biotic and abiotic determinants of the diet of brook trout, Salvelinus fontinalis, in lakes of the Laurentian Shield. Can. J. Fish. Aquat. Sci. 1992, 49, 1001-1009. [CrossRef]

49. Sotiropoulos, J.C.; Nislow, K.H.; Ross, M.R. Brook trout, Salvelinus fontinalis, microhabitat selection and diet under low summer stream flows. Fish. Manag. Ecol. 2006, 13, 149-155. [CrossRef]

50. Kownacki, A.; Dumnicka, E.; Kwandrans, J.; Galas, J.; Ollik, M. Benthic communities in relation to environmental factors in small high mountain ponds threatened by air pollutants. Boreal Environ. Res. 2006, 11, 481-492.

51. Dumnicka, E.; Boggero, A. Freshwater Oligochaeta in two mountain ranges in Europe: The Tatra Mountains (Poland) and the Alps (Italy). Fund. Appl. Limnol. 2007, 168, 231-242. [CrossRef]

52. Hyslop, E.J. Stomach contents analysis - a review of methods and their application. J. Fish. Biol. 1980, 17, 411-429. [CrossRef]

53. Eby, L.A.; Roach, W.J.; Crowder, L.B.; Stanford, J.A. Effects of stocking-up freshwater food webs. Trends Ecol. Evol. 2006, 21, 576-584. [CrossRef]

54. Nakano, S.; Murakami, M. Reciprocal subsidies: Dynamic interdependence between terrestrial and aquatic food webs. Proc. Natl. Acad. Sci. USA 2001, 98, 166-170. [CrossRef]

55. Baxter, C.V.; Fausch, K.D.; Carl Saunders, W. Tangled webs: Reciprocal flows of invertebrate prey link streams and riparian zones. Freshw. Biol. 2005, 50, 201-220. [CrossRef]

56. Baxter, C.V.; Fausch, K.D.; Murakami, M.; Chapman, P.L. Fish invasion restructures stream and forest food webs by interrupting reciprocal prey subsidies. Ecology 2004, 85, 2656-2663. [CrossRef]

57. Knight, T.M.; McCoy, M.W.; Chase, J.M.; McCoy, K.A.; Holt, R.D. Trophic cascades across ecosystems. Nature 2005, 437, 880. [CrossRef]

58. Leisner, J.J.; Laursen, B.G.; Prévost, H.; Drider, D.; Dalgaard, P. Carnobacterium: Positive and negative effects in the environment and in foods. FEMS Microbiol. Rev. 2007, 31, 592-613. [CrossRef] [PubMed]

59. Ramia, N.E.; El Kheir, S.M.; Taha, S.; Mangavel, C.; Revol-Junelles, A.M.; Borges, F. Multilocus sequence typing of Carnobacterium maltaromaticum strains associated with fish disease and dairy products. Appl. Microbiol. 2019, 126, 377-387. [CrossRef] [PubMed]

60. Loch, T.P.; Xu, W.; Fitzgerald, S.M.; Faisal, M. Isolation of a Carnobacterium maltaromaticum-like bacterium from systemically infected lake whitefish (Coregonus clupeaformis). FEMS Microbiol. Lett. 2008, 288, 76-84. [CrossRef]

61. Zlotkin, A.; Chilmonczyk, S.; Eyngor, M.; Hurvitz, A.; Ghittino, C.; Eldar, A. Trojan horse effect: Phagocyte-mediated Streptococcus iniae infection of fish. Infect. Immun. 2003, 71, 2318-2325. [CrossRef]

62. Köck, G.; Triendl, M.; Hofer, R. Seasonal patterns of metal accumulation in Arctic char (Salvelinus alpinus) from an oligotrophic Alpine lake related to temperature. Can. J. Fish. Aquat. Sci. 1996, 53, 780-786. [CrossRef]

63. European Commission. Commission Regulation (EC) No 1881/2006 of 19 December 2006 setting maximum levels for certain contaminants in foodstuffs. OJEC 2006, 364, 324-365.

64. Rognerud, S.; Grimalt, J.O.; Rosseland, B.O.; Fernandez, P.; Hofer, R.; Lackner, R.; Lien, L.; Massabuau, J.C.; Ribes, A. Mercury and organochlorine contamination in Brown trout (Salmo trutta) and Arctic charr (Salvelinus alpinus) from high mountain lakes in Europe and the Svalbard archipelago. Water Air Soil Pollut. 2002, 2, 209-232. [CrossRef]

65. Council of the European Commission. Council Directive 92/43/EEC of 21 May 1992 on the conservation of natural habitats and of wild fauna and flora. OJEC 1992, 206, 1-9.

(C) 2020 by the authors. Licensee MDPI, Basel, Switzerland. This article is an open access article distributed under the terms and conditions of the Creative Commons Attribution (CC BY) license (http://creativecommons.org/licenses/by/4.0/). 